\title{
Nutrient release dynamics in decomposing leaf litter in two Mediterranean deciduous oak species
}

\author{
I Santa Regina ${ }^{1 *}$, M Rapp $^{2}$, A Martin $^{1}$, JF Gallardo ${ }^{1}$ \\ 'IRNA/CSIC, Cordel de Merinas 40, 37008 Salamanca Spain; \\ ${ }^{2}$ CEFE/CNRS, BP 5051, Montpellier 34033, France
}

(Received 16 December 1996; accepted 23 May 1997)

\begin{abstract}
Summary - The release and dynamics of macronutrients from decomposing leaf litter were determined for two deciduous oak species: one in Spain, Quercus prrenaica, growing on a humic Cambisol (Sol brun forestier) and the other in France, $Q$ lamuginosa, on a rendsic Leptosol (Rendzine). The same processes were studied after leaf-litter exchanges between the French stand and a Spanish stand. Nylon litter bags $\left(1 \mathrm{~mm}^{2}\right.$ mesh), containing $10 \mathrm{~g}$ of leaves, were placed in five stands (four in Spain and one in France) and collected every 2 months when they were weighed and analysed for $\mathrm{N}, \mathrm{P}, \mathrm{Ca}, \mathrm{Mg}$ and $\mathrm{K}$. The mean amount of nutrients in the decomposing leaves decreased over the 36-month period. The four $Q$ pyrenaica stands were classified into two groups involving different nutrient release processes, without any relation to yearly litterfall. For the $Q$ lanuginosa stand, the results obtained were similar to those for one of the $Q$ pyrenaica groups. Similar nutrient release processes occurred in the litter-bags collected from native stands and after exchanges between the two species, with a quick release of $\mathrm{K}$, followed by $\mathrm{Mg}$ and $\mathrm{P}$. Higher $\mathrm{Ca}$ accumulation was noted for the $Q$ pyrenaica litter as compared to $Q$ lanuginosa litter. For N, the results were very different between the two species and the two locations.
\end{abstract}

litter decomposition / litter bags / nutrient release / oak coppice / Quercus pyrenaica / $Q$ lanuginosa

Résumé - Dynamique de libération des bioéléments de feuilles en décomposition de deux taillis méditerranéens à chênes caducifoliés. La dynamique qualitative et quantitative de la perte d'éléments majeurs à partir de litières de feuilles en décomposition a été établie pour deux espèces de chênes caducifoliés, l'une en Espagne : Quercus pyrenaica, implantée sur Cambisols humifères (sols brun forestier), l'autre en France : Quercus lanuginosa, implantée sur Leptosols rendsiques (Rendzines). Les mêmes mécanismes ont été étudiés après échange de litières entre la station française et une station espagnole. Des sachets de nylon, de maille de $1 \mathrm{~mm}^{2}$, contenant chacun $10 \mathrm{~g}$ de feuilles ont été déposés dans cing stations (quatre en Espagne et une en France) et des échantillons récoltés tous

\footnotetext{
* Correspondence and reprints

Tel: (34) 23219606 ; fax: (34) 23219609 ; e-mail: ignac@gugu.usal.es
} 
les 2 mois. Sur ces échantillons on a dosé : N, P, Ca, Mg et K. Les teneurs en éléments majeurs des feuilles diminuent au cours des 36 mois d'étude. Les quatre stations à $Q$ pyrenaica peuvent être regroupées en deux groupes, indiquant des processus de décomposition différents, sans relation avec les quantités de litière arrivant annuellement au sol. Pour $Q$ lanuginosa, les résultats étaient similaires à l'un des deux couples espagnols. Au cours de l'expérience d'échange de litières, des dynamiques semblables ont été observées dans les stations d'origine des litières et après échange. K est libéré le plus rapidement, suivi de $\mathrm{Mg}$ et de $\mathrm{P}$. On a trouvé une accumulation relative de Ca dans les litières de $Q$ pyrenaica, supérieure à celle des litières de $Q$ lanuginosa. Concernant l'azote les résultats sont variables, à la fois entre les deux espèces et entre les deux localités.

décomposition de la litière / perte d'éléments / décomposition en sachets / taillis / Quercus pyrenaica / Quercus lanuginosa

\section{INTRODUCTION}

Release of nutrients from decomposing litter is an important internal pathway for nutrient flux in forested ecosystems. Nutrients may be released from litter by leaching or mineralization (Swift et al, 1979). Nutrient release from decomposing litter affects ecosystem primary productivity (Blair, 1988), since these nutrients thus become available for plant uptake and are not lost from the system.

The rate at which nutrients are released depends on several factors as indicated by Seastedt (1984): chemical composition of the litter, structural nature of the nutrient in the litter matrix, microbial demand for the nutrient, and availability of exogenous sources of nutrients. Litter release factors are: litter quality (Fogel and Cromack, 1977; Aber and Melillo, 1980; Berg and Staaf, 1980, 1981; Melillo et al, 1982), macro- and microclimatic variables (Meentemeyer, 1978), microbial and faunal biotic activity (Reichle, 1977). Several authors have defined litter quality in terms of initial $\mathrm{N}$ concentrations, the $\mathrm{C} / \mathrm{N}$ ratio, initial lignin concentrations, and the lignin/ $\mathrm{N}$ ratio. Litter quality affects not only the rates of mass loss, but also the patterns and rates of nutrient immobilization or release. Climatic factors influencing litter decomposition rates include soil temperature (Lousier and
Parkinson, 1976; Heal, 1979; Edmonds, 1980; Moore, 1986; Witkamp, 1996), and soil moisture (Hayes, 1965). Soil fertility is directly related to the activity of decomposers (Bocock and Gilbert, 1957; Witkamp and Van der Drift, 1961).

In nature, it is often difficult to separate the effects of individual factors. Both interand intra-site differences in decomposition rates could reflect variations in several of the above-mentioned types of factors.

Element release is above mass loss if biotic mineralization processes are not necessary or if the nutrients are not structurally bound in the litter; it is below mass loss if the nutrients are in short supply relative to microbial demand and then accumulate in the litter during early phases of decompostion (Berg and Staaf, 1981).

The aim of this study was to compare the release of nutrients from decomposing litter of two species of Mediterranean deciduous oaks ( $Q$ pyrenaica Willd and $Q$ lanuginosa Lamk), characteristic of climax formations. The stands are located on forest plots differing in their geological substrates and microclimates. A reciprocal exchange of leaves from the two species between two stands was also studied in order to determine the effects of climatic and leaf quality factors (Martín et al, 1994). 


\section{MATERIAL AND METHODS}

\section{Site description}

The four $Q$ pyrenaica forest plots are situated on the northern slope of the 'Sierra de Gata' mountains in the southwestern part of Salamanca province (Spain). The $Q$ lanuginosa plot is in the Causse Mejean, north-west of Montpellier (France).

The climatic, edaphic and stand data are given in table I. There was a rainfall gradient between Navasfrías and Fuenteguinaldo. The 3 years of the study of decomposition were considered dry, since mean precipitation was $10-40 \%$ lower than the general averages. The annual mean precipitation was very similar between La Viale and $\mathrm{El}$ Payo (Moreno et al, 1993).

However, although there were no great differences in climatic factors or elevation between the four Spanish plots and the La Vialle plot, there was a notable lithological difference. The latter stand is located on dolomitic calcareous bedrock, with a rendzic Leptosol, whereas the four Spanish forest areas lie on acid bedrock (granite or shale), producing humic Cambisols (FAO, 1989).

Tree densities varied from 406 trees ha ${ }^{-1}$, with a mean diameter of $25 \mathrm{~cm}$ at El Payo, to 2100 trees ha ${ }^{-1}$, with a mean diameter of $9.5 \mathrm{~cm}$ at $\mathrm{La}$ Vialle, reflecting different coppice managements.

The following annotation is used for the plots: Navasfrías: NF; El Payo: EP; Villasrubias: VR; Fuenteguinaldo; FG; La Viale: LV.

\section{Local leaf litter}

In each of the five plots studied (four in the 'Sierra de Gata', Province of Salamanca and one in LV, near Montpellier), 54 nylon litter bags

Table I. Characteristics of the five stations studied (Martín et al, 1994).

\begin{tabular}{|c|c|c|c|c|c|}
\hline \multirow[b]{3}{*}{ Plot characteristics } & \multicolumn{5}{|c|}{ Forest ecosystem } \\
\hline & \multicolumn{4}{|c|}{ Q pyrenaica } & \multirow{2}{*}{$\begin{array}{c}\begin{array}{c}\mathrm{Q} \\
\text { lanuginosa }\end{array} \\
\text { La Vialle }\end{array}$} \\
\hline & Fuenteguinaldo & Villasrubias & El Payo & Navasfrias & \\
\hline Elevation (m) & 870 & 900 & 940 & 960 & 1000 \\
\hline Geology & granite & schist & granite & schist & $\begin{array}{l}\text { dolomitic } \\
\text { limestone }\end{array}$ \\
\hline Soil units & \multicolumn{4}{|c|}{${ }_{-}$Humic Cambisol —__ } & Rendzina \\
\hline Humus type & forest mull & forest mull & forest mull & forest mull & calcic mull \\
\hline $\mathrm{pH}$ & 5.3 & 5.1 & 5.0 & 5.0 & 7.6 \\
\hline OM $(\%)$ & 7.3 & 12.0 & 13.0 & 18.0 & 10.0 \\
\hline $\mathrm{C} / \mathrm{N}$ & 15.0 & 19.0 & 17.0 & 19.0 & 14.5 \\
\hline $\mathrm{CEC}\left(\mathrm{cmol} \mathrm{kg} \mathrm{kg}^{-1}\right)$ & 19.6 & 24.5 & 26.0 & 25.4 & 28.6 \\
\hline Avail $\mathrm{P}_{2} \mathrm{O}_{5}\left(\mathrm{mg} \mathrm{kg}^{-1}\right)$ & 385 & 51.1 & 77.2 & 50.0 & 450 \\
\hline Density $\left(\right.$ tree ha $\left.{ }^{-1}\right)$ & 738 & 1043 & 406 & 820 & 2100 \\
\hline Tree mean diameter $(\mathrm{cm})$ & 16.5 & 11.0 & 25.4 & 15.2 & 9.5 \\
\hline Tree mean height $(\mathrm{m})$ & 12.0 & 8.5 & 17.0 & 13.0 & 7.0 \\
\hline Long-term mean $\mathrm{P}\left(\mathrm{mm} \mathrm{yr}^{-1}\right)$ & 720 & 872 & 1245 & 1580 & 900 \\
\hline 3 years mean $\mathrm{P}\left(\mathrm{mm} \mathrm{yr}^{-1}\right)$ & 568 & 767 & 859 & 969 & 843 \\
\hline Mean annual $\mathrm{t}\left({ }^{\circ} \mathrm{C}\right)$ & 13.3 & nd & nd & 5.5 & 4.8 \\
\hline
\end{tabular}

OM: soil organic matter; CEC: total cation exchange capacity; Avail: available; P: rainfall; t: temperature; Nd: no data available. 
with $1 \mathrm{~mm}^{2}$ mesh and a surface area of $400 \mathrm{~cm}^{2}$ (each containing $10 \mathrm{~g}$ of leaves collected from each site) were placed over the litter in three different locations on each plot. The litter contained in the bags had been dried at room temperature, the remaining humidity being determined by drying at $80^{\circ} \mathrm{C}$ until constant weight was achieved. Every 2 months, beginning in February 1990 , three bags per plot (one from each location) were collected over a period of 3 consecutive years. The leaves were dried (at $80^{\circ} \mathrm{C}$ ) and weighed in the laboratory. Temperature should have been $105^{\circ} \mathrm{C}$, but above $80^{\circ} \mathrm{C}$ there is a risk of loss of organic matter and minerals (Hernández et al, 1995).

\section{Leaf litter exchanged}

Beginning in February 1991 and using the same study method for 2 consecutive years, leaves were exchanged between the EP and LV plots (36 litter bags placed in three groups).

\section{Methods}

The following methods were used for chemical analysis of the different litter components: total $\mathrm{N}$ determined by the Kjeldahl method or with a Macro-N Heraeus analyzer; total $P$ by spectrophotometry using the vanadomolibdophosphoric yellow method; total $\mathrm{Ca}$ and $\mathrm{Mg}$ by atomic absorption spectroscopy, and total $\mathrm{K}$ by flame photometry (Hernández et al, 1995).

In order to establish possible significant differences in mass loss for the different plots studied, a one-factor Anova was applied with repeated measures for times. Hartley's test had been previously implemented to verify the nature of the variances. Wilcoxon's test was applied to the data obtained in relation to the leaf exchange experiments.

\section{RESULTS AND DISCUSSION}

\section{Leaf-litter decomposition}

Litter weight loss over 3 years of decomposition has been studied previously (Martín et al, 1994). The main results obtained here indicated that decomposition was slowest at VR-EP, and more intense in LV, intermediate results being obtained for the NF-FG sites, although closer to the LV levels.

Regressions for time ( $\mathrm{t}=$ time in months) and percentage decomposition $(\% \mathrm{dec}) \mathrm{cal}$ culated from the mean decomposition rates at VR-EP and also at NF-FG-LV gave the following equations:

$$
\begin{array}{lrl}
\text { VR-EP: } \quad \% \text { Dec }=4.29 . t^{0.707} & r=0.967 \\
\text { NV-FG-LV:\%Dec }=4.38 . t^{0.746} & r=0.966
\end{array}
$$

These equations indicated half-decomposition times ( $50 \%$ of the initial matter) of 32 months for the first group (EP, VR) and 26 months for the second (NF, FG and LV).

The results in the literature are sometimes conflictive since they are based on both field (in situ) and laboratory (in vitro) studies. Bockheim et al (1991) obtained a decomposition rate of $50 \%$ for 25 months in $Q$ ellipsoidalis, while Rapp (1967), under controlled moisture conditions, recorded half-decomposition times in $Q$ ilex, $Q$ coccifera and for other $Q$ lanuginosa leaves after 22 months of decomposition.

These observations indicated that leaf decomposition patterns were similar for both oak species, but occurred at different rates. Seasonal variations played a major role, with a deceleration or interruption of decomposition in summer (due to drought and typical Mediterranean high temperatures; Martín et al, 1994) and more active decomposition from autumn to spring.

Apart from the intra-annual role of climate, it also appears to be important at a global scale. Thus, LV the northernmost stand studied, showed the highest decomposition rate. However, it could not be determined whether the less intense summer drought, or the geological and soil properties (soils with abundant calcium), were responsible for the differences relative to the four 
plots of Sierra de Gata; probably, both factors were involved (Martín et al, 1994).

On the basis of these litter weight loss data and its chemical composition, the following were successively investigated:

1) variations in litter nutrient concentrations at various decomposition times and relative to the initial nutrient content;

2) variations in absolute nutrient mass during decomposition relative to nutrients in yearly litterfall.

\section{Relative release of nutrients from litter bags}

Nutrient concentrations, expressed as a percentage of initial concentrations, are shown in figures 1-5. The same data after 1,2 and 3 years of decomposition and the mean chemical composition of leaves at the same time are summarized in table II.

The mean concentration of $\mathrm{N}$ in the leaves relative to the initial concentration decreased over the 36-month period (fig 1 ).
However, for two stands (LV and EP) an initial increase was observed, with a maximum concentration of $140 \%$ in the LV stand after almost 2 months.

Net $N$ release began after 2 months in $\mathrm{LV}$, after 6 months in $\mathrm{EP}$, and from the outset in the other stands (fig 1). The greatest $\mathrm{N}$ loss was seen in the FG stand after 25 months. At VR and LV $85 \%$ of the original $\mathrm{N}$ from the litter bags still remained at the end of the experiments (table II). An increase in $\mathrm{N}$ was noted at NF and FG at the end of the experiments with respect to the other years (table II).

Many workers (Bocock, 1963; Gosz et al, 1973; Will, 1967; Edmonds, 1979) have noted increased $\mathrm{N}$ concentrations in leaves during the decomposition process. Gosz et al (1973) have suggested that this increase probably arises from external sources such as precipitation, atmospheric dust and invasion of litter bags by fungal hyphae.

Initial $P$ loss was very rapid in all stands during the first 2 months (fig 2). The concentration then remained at a steady level for 6 months in VR, FG and EP while it

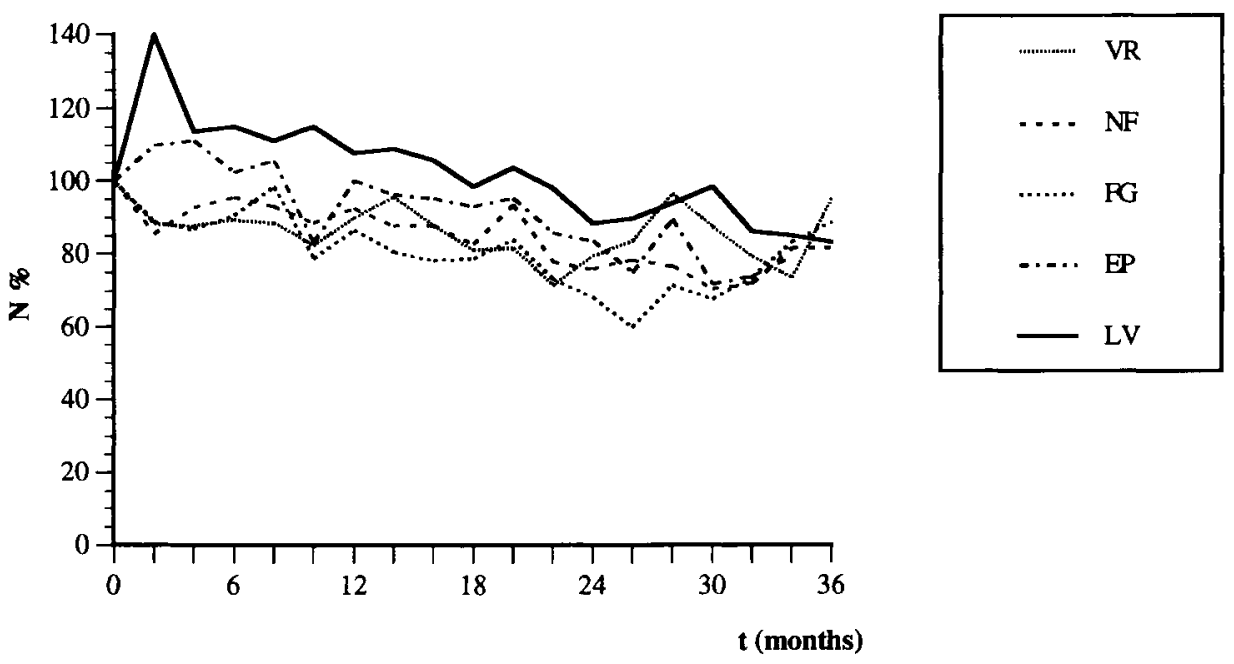

Fig 1. Mean nitrogen contents in decomposing leaves at the five studied sites over 3 years. 


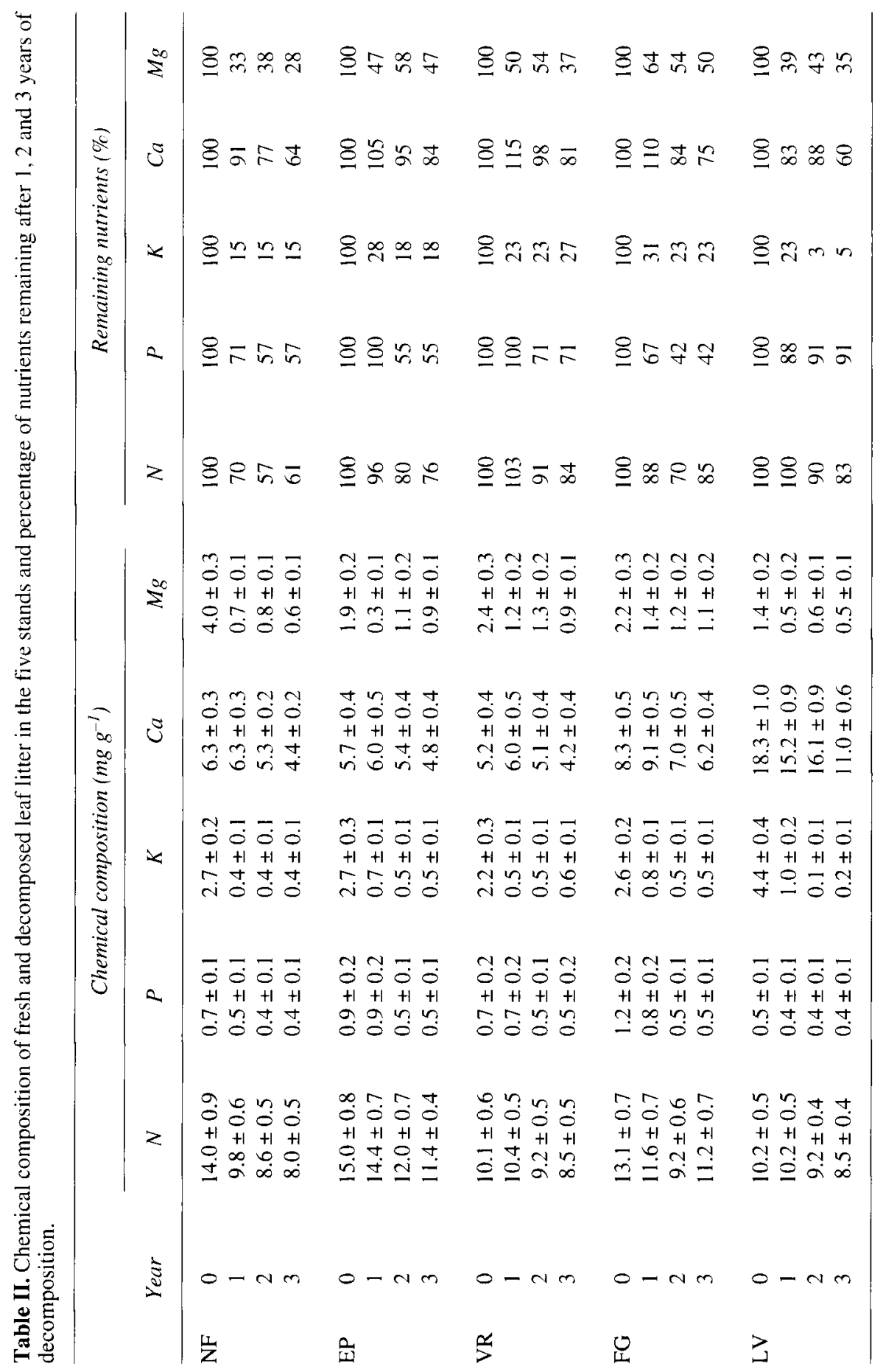




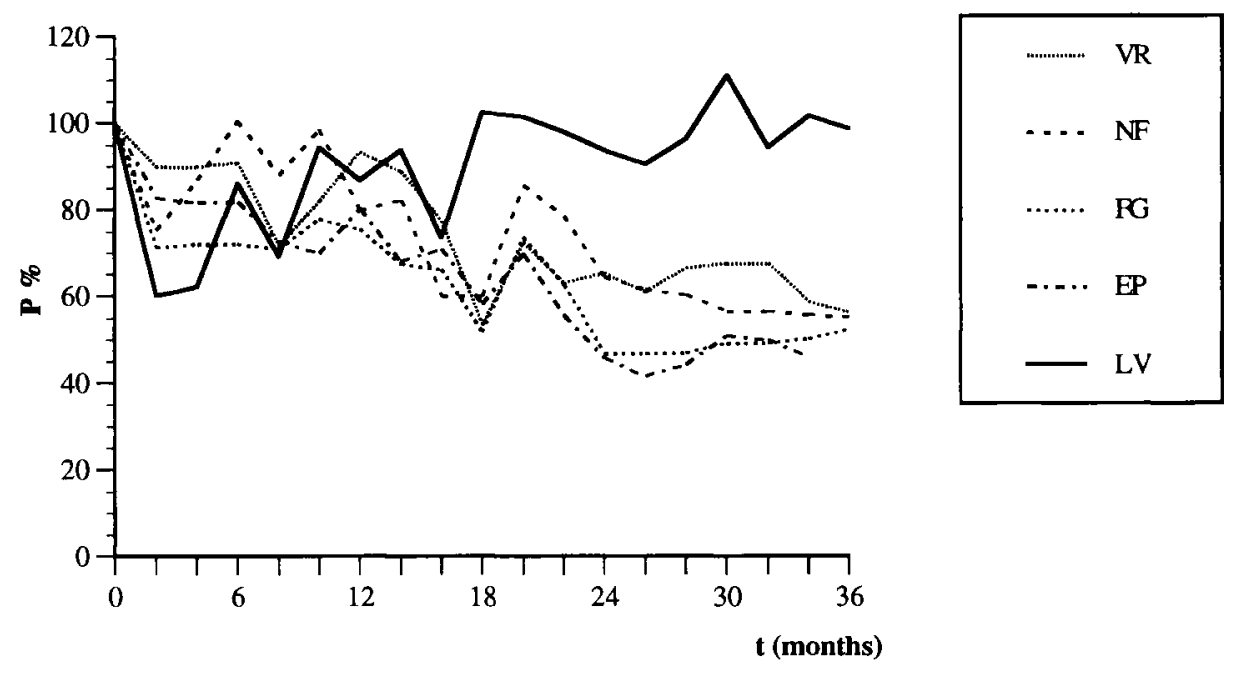

Fig 2. Mean phosphorus contents in decomposing leaves at the five studied sites over 3 years.

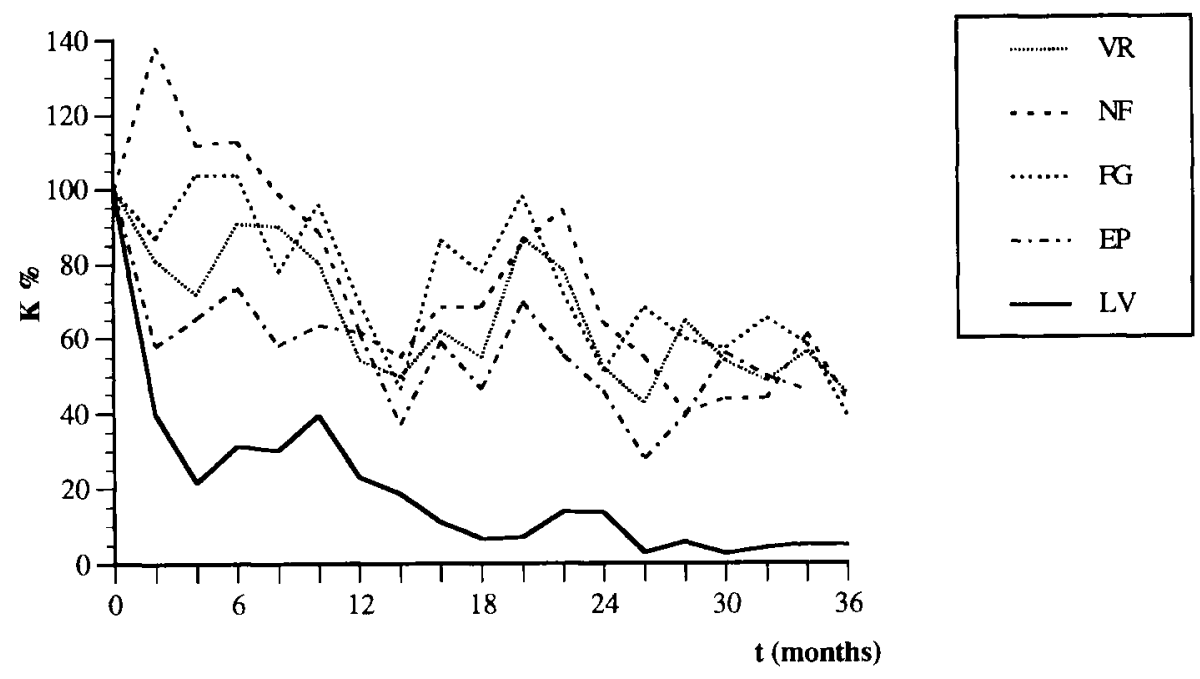

Fig 3. Mean potassium contents in decomposing leaves at the five studied sites over 3 years.

increased in NF and LV. Strong phosphorus release also occurred at 14 and 20 months.

At the end of the 3 years (table II) the greatest differences were noted between LV and FG. At LV, the phosphorus concentra- tion remained practically constant: $91 \%$ of the initial amount was still present. Hernández et al (1995) reported a relative increase during decomposition, but only $55 \%$ of the initial $P$ remained at the end of the experi- 


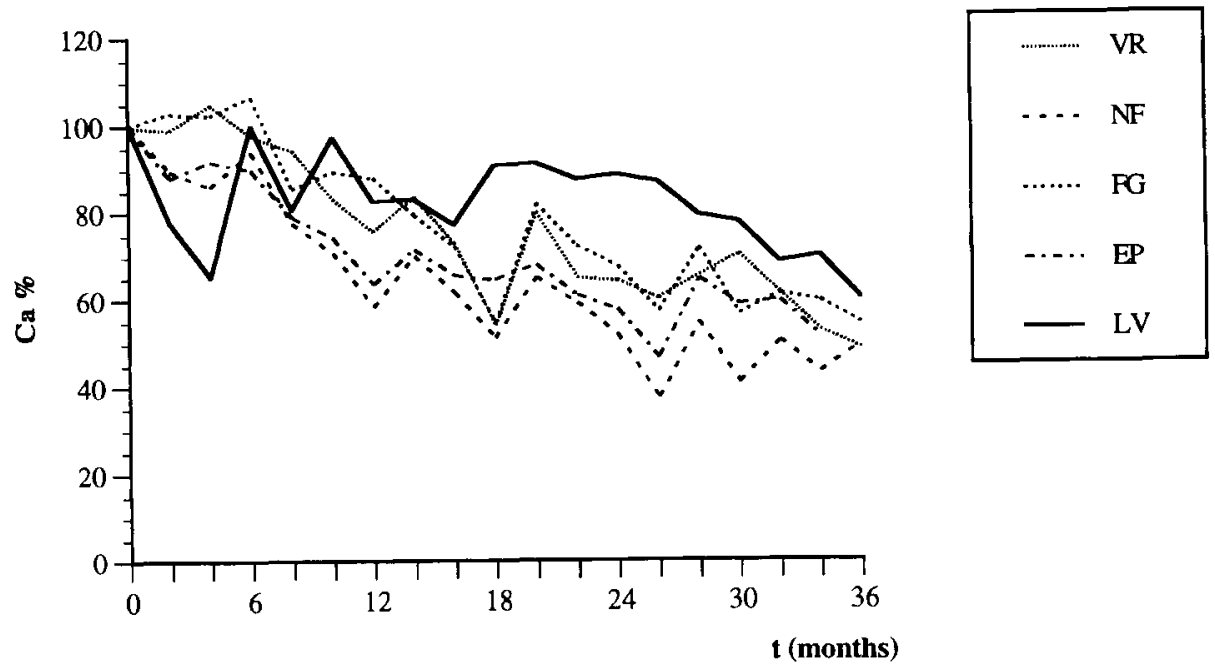

Fig 4. Mean calcium contents in decomposing leaves at the five studied sites over 3 years.

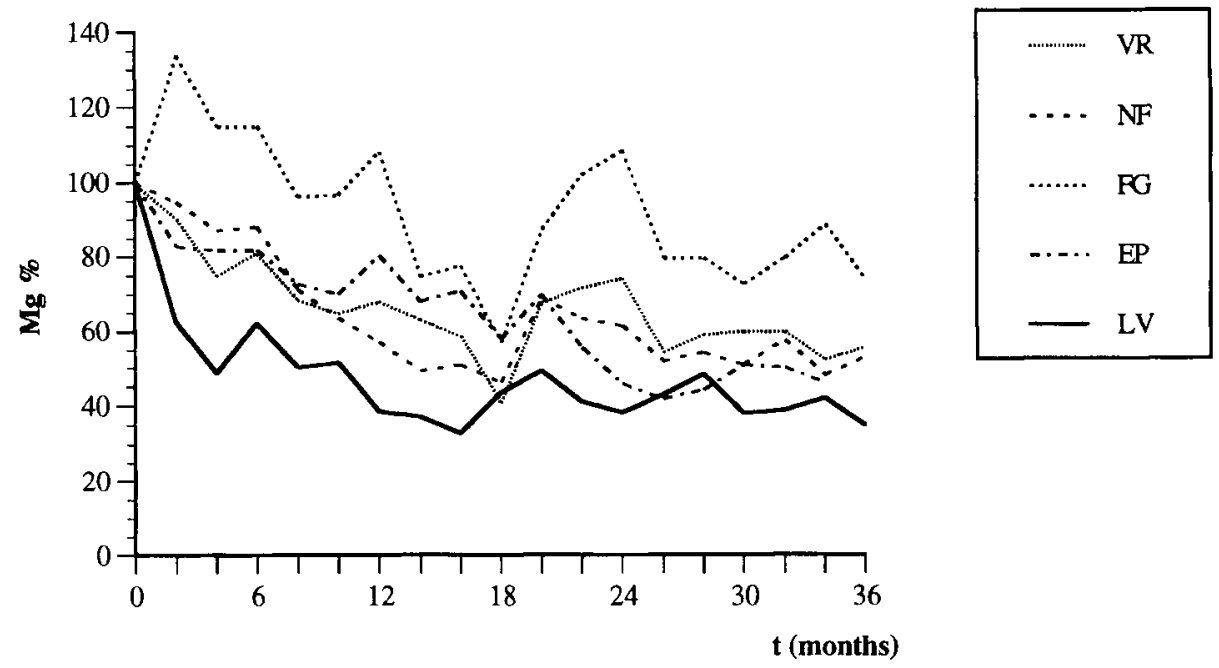

Fig 5. Mean magnesium contents in decomposing leaves at the five studied sites over 3 years.

ments. For Berg and Staaf (1980), the phosphorus release pattern was similar to that of N.

Initial Ca concentrations were ranked as follows:

$$
\mathrm{LV}>\mathrm{FG}>\mathrm{NV} \approx \mathrm{EP}>\mathrm{VR}
$$

Calcium concentrations increased slightly over the first 6 months in the VR and FG stands (fig 4) and decreased in NV, EP and, more markedly, in the LV stand with respect 
to the soil contents of this element. Similar results were obtained by Bockheim et al (1991).

As shown in table II, after a relative accumulation during the first years in litter bags, calcium showed lower rates of decrease as compared to the other nutrients. After 3 years of experiments $84 \%$ in EP, $81 \%$ in VR, $75 \%$ in FG, and 64 and $60 \%$ of the initial $\mathrm{Ca}$ in the NF and LV plots, respectively, still remained. This could result from the association of $\mathrm{Ca}$ with resistant compounds such as cellulose (Schlesinger, 1985), or Ca inclusion within cell walls.

During leaf decomposition the relative concentration of $\mathrm{Mg}$ decreased during the first season in the VR, NV, EP and LV stands, but increased in the FG plot (fig 5). Thereafter, $\mathrm{Mg}$ remained more or less stable in all stands, except in the FG plot midway through the experiments. Here, there was marked release of $\mathrm{Mg}$ followed by a sharp increase (fig 5). At FG, $50 \%$ of the initial $\mathrm{Mg}$ concentration remained after 3 years of decomposition; this was similar to EP $(47 \%)$. $\mathrm{Mg}$ release was higher for VR and LV with 37 and $35 \%$ remaining, respectively, and for NF, where only $28 \% \mathrm{Mg}$ remained at the end of 3 years of leaf decomposition in litter bags (table II). Berg and Staaf (1981) indicated that this is not a limiting bioelement, and Hernández et al (1995) confirmed that there is a parallel with the loss of dry matter and carbon. It should be stressed that the imbalance of $\mathrm{Ca} / \mathrm{Mg}$ in NF (Martín et al, 1994) gives higher values of $\mathrm{Mg}$ and lower values of $\mathrm{Mg}$ in $\mathrm{LV}$; this could explain such patterns.

Potassium was most readily lost from litter bags from all stands, except for NF which showed a substantial increase over the initial 3 months (fig 3). The greatest $\mathrm{K}$ loss was noted at the end of the experiments, especially at $\mathrm{LV}$. The remaining amounts of $\mathrm{K}$ were very similar at EP, VR and FG: 18, 27 and $23 \%$, respectively, and then at NF and LV: 15 and 5\% (table II).
The concentration of $\mathrm{K}$ decreased for both species considered. All studies published report a similar loss of K (Bockheim et al, 1991; Hernández et al, 1995). Contrary to $\mathrm{N}$ and $\mathrm{P}, \mathrm{K}$ is not bound as a structural component in plants and is highly water soluble (Gosz et al, 1973). In $Q$ rotundifolia leaves, Hernández et al (1995) found losses of $30-40 \%$ with respect to the initial content during the first 4 months of decomposition. This is in accordance with the abundance and solubility of this bioelement. Later losses were smaller, $10 \%$ of the initial amount remaining at the end of the second year. Berg and Staaf (1980) attributed this second phase to the retention of $\mathrm{K}$ to fulfill the needs of decomposers.

\section{Amounts of nutrients released from the yearly litter in the five sites studied}

From the results of nutrient release in the litter bags it was possible to estimate nutrient fluxes at the different sites and for the two species in relation to yearly litterfall (table III). The yearly amounts of nutrients released were also determined (table IV).

Table III summarizes the amounts of nutrients ( $\mathrm{N}, \mathrm{P}, \mathrm{Ca}, \mathrm{Mg}$ and $\mathrm{K}$ ) returned each year during the 3 years of decomposition and which are again available for uptake by the trees.

Similar nutrient release balances during litter decomposition were observed by Bockheim et al (1991) for $Q$ ellipsoidalis and Hanchi (1994) for Fagus sylvatica.

The four $Q$ pyrenaica stands can be subdivided into two groups, clearly indicating different nutrient release processes for decomposing litter: NV and FG is the first group, EP and VR is the other. As a result, no relation between the amount of annual litterfall and annual nutrient release was found. Additionally, these two groups were not affected by geology or climate. 
Litter decomposition and nutrient release processes seem to be independent of the amount of available litter and climatic patterns.

Concerning the $Q$ lanuginosa stand, the results were similar to those obtained for NV and FG.

\section{Nutrient release after leaf litter exchange between $Q$ pyrenaica and $Q$ lanuginosa}

Leaf litter samples from EP ( $Q$ pyrenaica) and LV (Q lanuginosa) were studied for 2 years in native stands after exchange between the two stands, using the litter bag methodology ( 36 litter bags placed in three groups beginning in February 1991, three bags per plot every 2 months). Figures 6 to 9 indicate the dynamics of the nutrients released during 2 years of leaf litter decomposition in litter bags.

Similar nutrient release processes occurred in both situations: litter bags in native stands and after exchange between the two stands, with rapid release of $\mathrm{K}$, followed by $\mathrm{Mg}$ and $\mathrm{P}$. There was high $\mathrm{Ca}$ accumulation in the EP litter as compared to that of LV. For N, the results were very different between the two species and the two locations. Leaf litter from LV indicated only a slight $\mathrm{N}$ accumulation during the first months of decomposition. For EP, leaf litter

Table HI. Litterfall and nutrient content remaining after 1,2 and 3 years of decomposition (in $\mathrm{kg} \mathrm{ha}^{-1}$; DM: dry matter).

\begin{tabular}{|c|c|c|c|c|c|c|c|}
\hline Plot & Years & $D M$ & $N$ & $P$ & $K$ & $C a$ & $M g$ \\
\hline \multirow{4}{*}{$\mathrm{NF}$} & 0 & $2088 \pm 224$ & $29.2 \pm 4$ & $1.5 \pm 0.3$ & $5.6 \pm 0.7$ & $14.4 \pm 2$ & $4.4 \pm 0.5$ \\
\hline & 1 & $1294 \pm 108$ & $20.4 \pm 3$ & $1.2 \pm 0.3$ & $0.9 \pm 0.2$ & $12.5 \pm 2$ & $1.5 \pm 0.3$ \\
\hline & 2 & $1044 \pm 97$ & $16.6 \pm 2$ & $0.9 \pm 0.2$ & $0.9 \pm 0.2$ & $11.2 \pm 2$ & $1.7 \pm 0.3$ \\
\hline & 3 & $814 \pm 86$ & $16.4 \pm 2$ & $0.7 \pm 0.2$ & $0.6 \pm 0.2$ & $9.7 \pm 2$ & $1.3 \pm 0.2$ \\
\hline \multirow{4}{*}{$\mathrm{EP}$} & 0 & $2346 \pm 231$ & $35.2 \pm 4$ & $2.1 \pm 0.4$ & $6.3 \pm 0.8$ & $13.4 \pm 3$ & $4.4 \pm 0.6$ \\
\hline & 1 & $1595 \pm 131$ & $33.8 \pm 4$ & $2.1 \pm 0.4$ & $1.6 \pm 0.4$ & $14.0 \pm 3$ & $2.2 \pm 0.4$ \\
\hline & 2 & $1314 \pm 118$ & $28.2 \pm 3$ & $1.2 \pm 0.2$ & $1.2 \pm 0.3$ & $12.7 \pm 3$ & $2.6 \pm 0.4$ \\
\hline & 3 & $1079 \pm 101$ & $26.7 \pm 3$ & $1.2 \pm 0.2$ & $1.2 \pm 0.3$ & $11.3 \pm 2$ & $2.0 \pm 0.4$ \\
\hline \multirow{4}{*}{ VR } & 0 & $2208 \pm 217$ & $22.3 \pm 3$ & $1.5 \pm 0.3$ & $4.9 \pm 0.7$ & $11.5 \pm 2$ & $5.3 \pm 0.6$ \\
\hline & 1 & $1501 \pm 126$ & $23.0 \pm 3$ & $1.6 \pm 0.3$ & $1.2 \pm 0.3$ & $13.2 \pm 3$ & $2.7 \pm 0.4$ \\
\hline & 2 & $1281 \pm 110$ & $20.4 \pm 5$ & $1.1 \pm 0.2$ & $1.1 \pm 0.2$ & $11.3 \pm 2$ & $2.9 \pm 0.5$ \\
\hline & 3 & $1038 \pm 92$ & $23.0 \pm 4$ & $0.9 \pm 0.2$ & $0.9 \pm 0.2$ & $8.0 \pm 2$ & $2.1 \pm 0.4$ \\
\hline \multirow{4}{*}{ FG } & 0 & $2829 \pm 246$ & $37.0 \pm 5$ & $3.4 \pm 0.4$ & $7.4 \pm 0.9$ & $23.5 \pm 4$ & $6.2 \pm 0.7$ \\
\hline & 1 & $1811 \pm 123$ & $32.8 \pm 4$ & $2.3 \pm 0.3$ & $2.2 \pm 0.3$ & $25.9 \pm 4$ & $4.0 \pm 0.6$ \\
\hline & 2 & $1320 \pm 97$ & $25.7 \pm 3$ & $1.4 \pm 0.2$ & $1.6 \pm 0.2$ & $19.8 \pm 3$ & $4.0 \pm 0.6$ \\
\hline & 3 & $1301 \pm 86$ & $32.3 \pm 4$ & $1.6 \pm 0.3$ & $1.8 \pm 0.3$ & $15.3 \pm 3$ & $2.6 \pm 0.4$ \\
\hline \multirow{4}{*}{ LV } & 0 & $2466 \pm 201$ & $24.2 \pm 3$ & $1.0 \pm 0.2$ & $11.0 \pm 2.0$ & $43.2 \pm 6$ & $3.7 \pm 0.5$ \\
\hline & 1 & $1615 \pm 120$ & $26.1 \pm 3$ & $0.9 \pm 0.2$ & $2.6 \pm 2.0$ & $35.7 \pm 5$ & $1.4 \pm 0.3$ \\
\hline & 2 & $1198 \pm 86$ & $21.7 \pm 2$ & $0.9 \pm 0.2$ & $0.5 \pm 0.1$ & $37.5 \pm 5$ & $1.6 \pm 0.3$ \\
\hline & 3 & $0858 \pm 48$ & $20.1 \pm 3$ & 0.0 & $0.5 \pm 0.1$ & $26.0 \pm 4$ & $1.3 \pm 0.2$ \\
\hline
\end{tabular}


decomposition remained steady for both situations: litter in the native stand or litter transferred to LV.

The release of nutrients after 2 years of decomposition, expressed as a percentage of the initial amount available in the yearly litterfall, is indicated in table $\mathrm{V}$.

For $\mathrm{N}$, the nutrient release dynamics were confirmed after 2 years of decomposition. The same amount of $\mathrm{N}$ was released from the EP leaves, with no differences in relation to the localization of litter bags. For $Q$ lanuginosa leaves, $\mathrm{N}$ release rates seemed to be higher in the native $\mathrm{LV}$ stand than after transfer to EP. Although ammonification and nitrification processes occurred at all sites, the biochemical composition of the leaves, probably varying between $Q$ pyrenaica and $Q$ lanuginosa, could interfere with the decomposition processes and be an explanation for the same mineralization for EP leaves irrespective of stand conditions (Martín et al, 1994).

$P$ release was more important in the leaves of $\mathrm{LV}$ placed in $\mathrm{EP}$, whereas no appreciable variation was observed. When the leaves from EP were placed in the two plots (EP, LV). The scarcity of this element may govern retention due to microbial activity.

The transfer of $Q$ pyrenaica litter from EP to $L V$ increased $K$ and $C a$ release from the decomposing litter, whereas litter transfer from LV to EP increased the release of

Table IV. Amounts of the five nutrients returning to the soil each year.

\begin{tabular}{cccc}
\hline Plots & $\begin{array}{c}\text { After I year After 2 years } \\
\left(k g h a^{-1}\right)\end{array}$ & $\begin{array}{c}\text { After } 3 \text { years } \\
(\mathrm{kg} \mathrm{hal})\end{array}$ & $\left(\mathrm{kg} \mathrm{ha^{-l } )}\right.$ \\
\hline NF & 18.6 & 5.4 & 2.6 \\
FG & 12.3 & 12.3 & 8.1 \\
EP & 8.3 & 7.6 & 3.5 \\
VR & 6.3 & 2.6 & 4.5 \\
LV & 18.3 & 4.6 & 14.3 \\
\hline
\end{tabular}

Ca and P from Q lanuginosa leaves. A possible explanation is that microrganisms may retain bioelements, which would also explain the reduced retention of $\mathrm{Ca}$ in the leaves on their own plot. Concerning $\mathrm{K}$ release, factors such as high soluble mineral and climatic patterns (eg, yearly precipitation distributions) were important. Rainfall events were more frequent at LV than at EP.

The stronger release of $\mathrm{Mg}$ always occurred in the native stand litter, even though the amount of leaf litter decomposition was higher after litter exchange between the two stands (Martín et al, 1994). Mg may be restricted in $\mathrm{LV}$ because it is a limiting factor for excess of $\mathrm{Ca}$.

\section{CONCLUSIONS}

The mean amount of nutrients in the decomposing leaves decreased over the 36-month period. The four $Q$ pyrenaica stands were classified into two groups involving different nutrient release processes, with no relationship to yearly litterfall. For the $Q$ lanuginosa stand, the results obtained were similar to those for one of the $Q$ pyrenaica groups. Similar nutrient release processes occurred in the litter bags collected from native stands and after exchanges between the two

Table V. Release of nutrients after 2 years of decomposition.

\begin{tabular}{lcccc}
\hline $\begin{array}{l}\text { Leaves } \\
\text { from: }\end{array}$ & $\begin{array}{c}\text { La Vialle } \\
(\%)\end{array}$ & \multicolumn{2}{c}{$\begin{array}{c}\text { El Pavo } \\
(\%)\end{array}$} \\
Plots at: & $L V$ & $E P$ & $E P$ & $L V$ \\
\hline $\mathrm{N}$ & 11 & 0 & 17 & 17 \\
$\mathrm{P}$ & 9 & 17 & 52 & 48 \\
$\mathrm{Ca}$ & 13 & 27 & 0 & 21 \\
$\mathrm{Mg}$ & 57 & 43 & 41 & 28 \\
$\mathrm{~K}$ & 97 & 77 & 81 & 95 \\
\hline
\end{tabular}




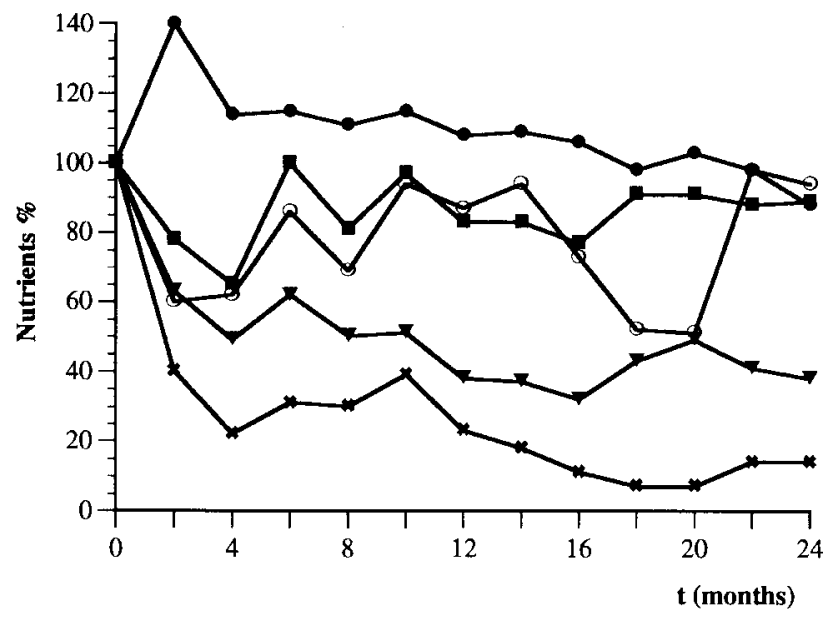

$$
\begin{aligned}
& \rightarrow \mathrm{N} \% \mathrm{LV} / \mathrm{LV} \\
& \rightarrow \mathrm{P} \% \mathrm{LV} / \mathrm{LV} \\
& \rightarrow \mathrm{K} \% \mathrm{LV} / \mathrm{LV} \\
& \rightarrow \mathrm{Ca} \% \mathrm{LV} / \mathrm{LV} \\
& \rightarrow \mathrm{Mg} \% \mathrm{LV} / \mathrm{LV}
\end{aligned}
$$

Fig 6. Nutrient release (\%) over 2 years from decomposing leaf litter. Litter from La Vialle at La Vialle (in \% of initial contents).
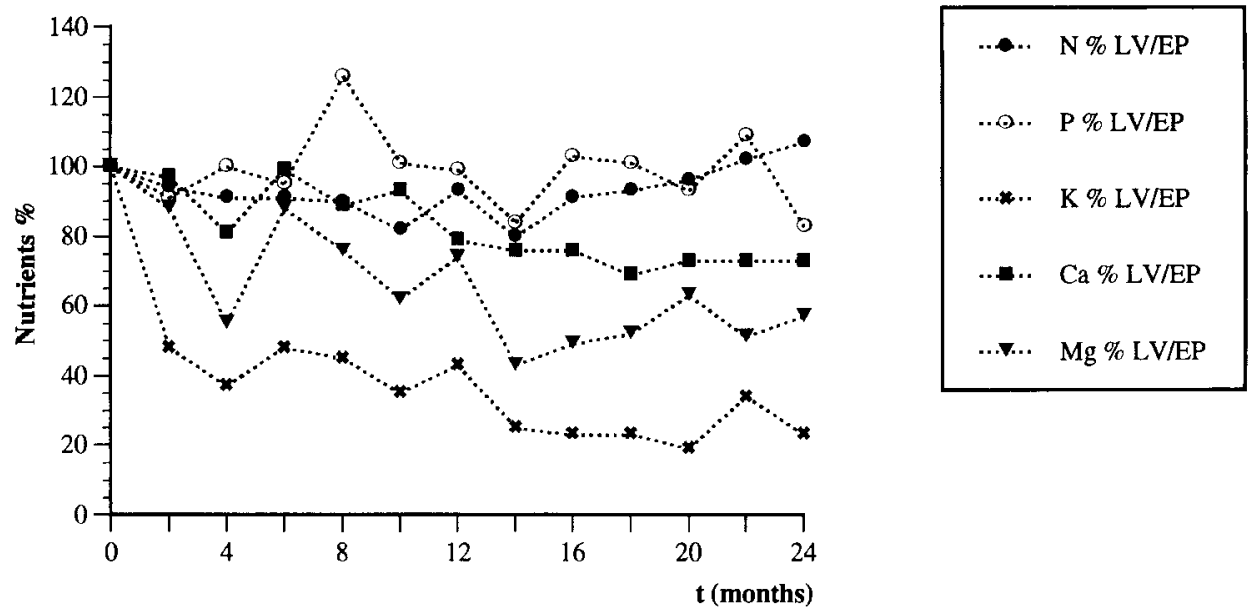

Fig 7. Nutrient release (\%) over 2 years from decomposing leaf litter. Litter from La Vialle at El Payo (in \% of initial contents).

species, with rapid release of $\mathrm{K}$, followed by $\mathrm{Mg}$ and $\mathrm{P}$. A stronger $\mathrm{Ca}$ accumulation was noted for the $Q$ pyrenaica litter as compared to that of $Q$ lanuginosa. For $\mathrm{N}$, the results differed considerably between the two species and two locations.
Acknowledgement: Economic support was received from the MEDCOP/AIR Program (GD XII, European Union), the Spanish CICYT Funds and 'Junta de Castilla y León'. The technical expertise of ML Cosme, J Hernandez, N Najac and $C$ Perez is acknowledged. The English version was revised by N Skinner. 

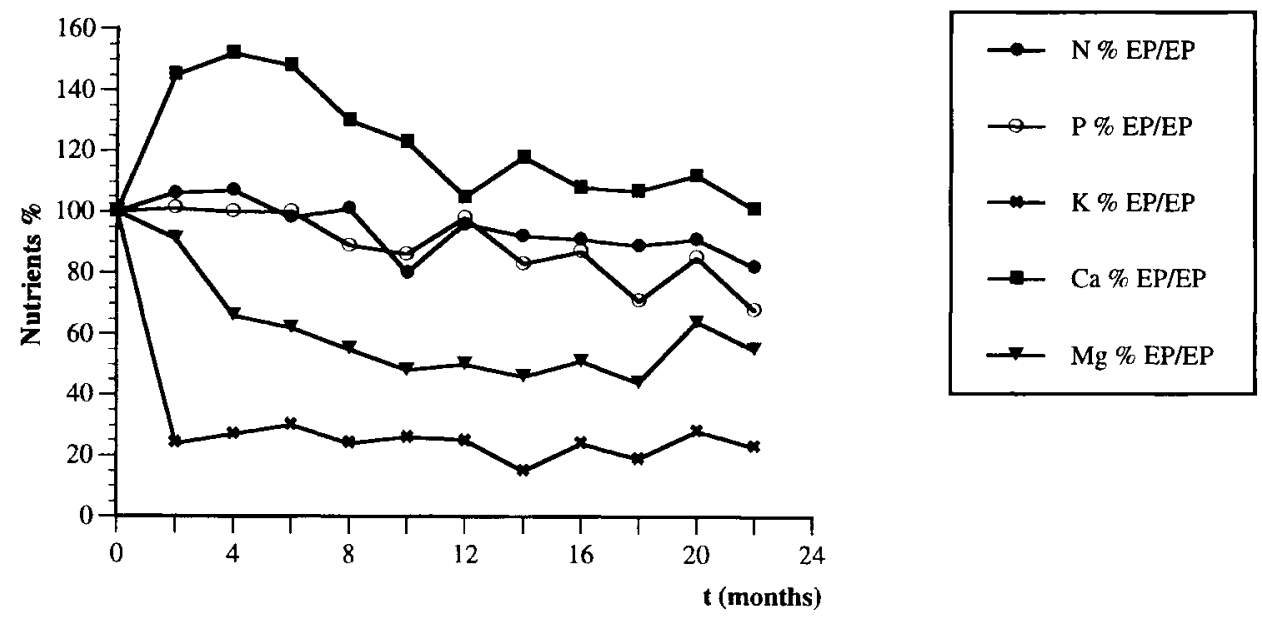

Fig 8. Nutrient release (\%) over 2 years from decomposing leaf litter. Litter from El Payo at El Payo (in \% of initial contents).
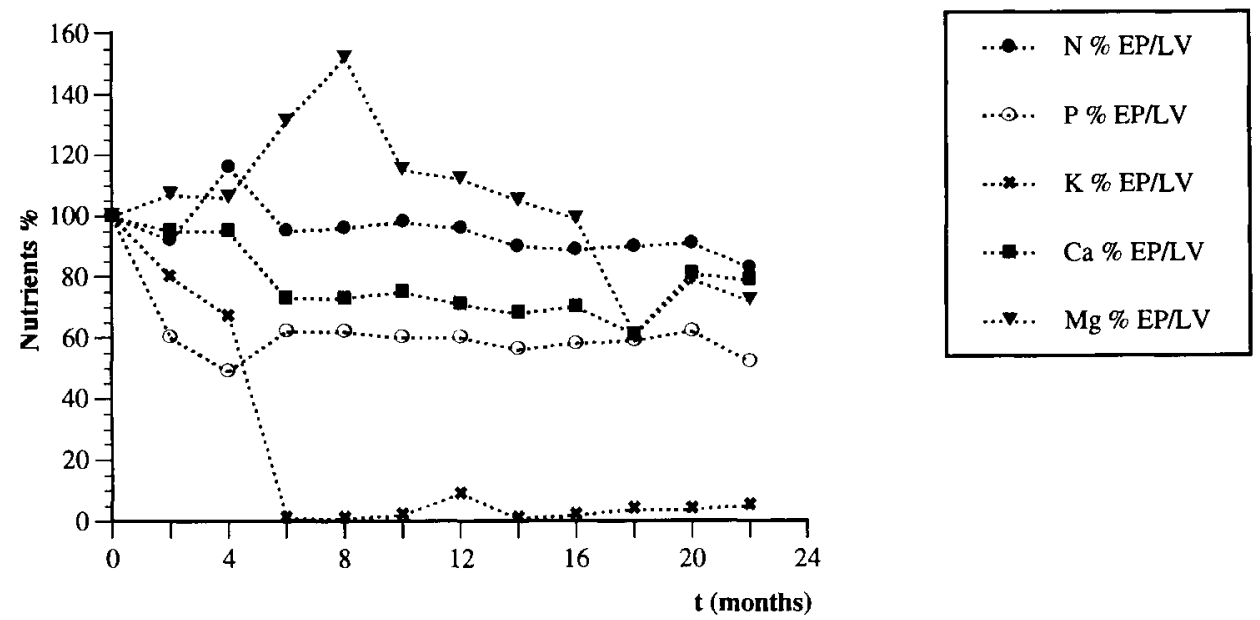

Fig 9. Nutrient release (\%) over 2 years from decomposing leaf litter. Litter from El Payo at La Vialle (in $\%$ of initial contents).

\section{REFERENCES}

Aber JD, Melillo JM (1980) Litter decomposition: measuring state of decay and percent transfer into forest soils. Can J Bot 58, 416-421.

Berg B, Staaf H (1980) Decomposition rate and chemical changes of Scots pine litter II. The influence of chemical composition. In: Structure and Function of Northern Coniferous Forest: An Ecosvstem Study (T Persson, ed), Ecol Bull (Stockholm) 32, 373390

Berg, Staaf H (1981) Leaching accumulation, and release of nitrogen in decomposing forest litter. In: Terrestrial Nitrogen Cvcles. Processes, Ecosvstem 
Strategies, and Management Impacts (FE Clark, T Rosswall, eds), Ecol Bull (Stockholm) 33, 163-178

Blair JM (1988) Nitrogen, sulfur and phosphorus dynamics in decomposing deciduous leaf litter in the Southern Appalachians. Soil Biol Biochem, 20, 693-701

Bockheim JG, Jensen EA, Heisey DM (1991) Nutrient dynamics in decomposing leaf litter of four tree species on a sandy soil in Northwestern Wisconsin. Can J For Res 21, 803-812

Bocock, KL ( 1963) Changes in the amounts of dry matter, nitrogen, carbon and energy in decomposing woodland leaf litter in relation to the activities of the soil fauna. $J E c o / 52,273-284$

Bocock, KL, Gilbert OJ (1957) The disappearance of leaf litter under different woodland conditions. Plant and Soil 9, 179-185

Edmonds RL (1979) Decomposition and nutrient release in Douglas-fir needle litter in relation to stand development. Can J For Res 1, 132-140

Edmonds RL (1980) Litter decomposition and nutrient release in Douglas-fir, red alder, Western hemlock, and Pacific silver fir ecosystems in Western Washington. Can J For Res 10, 327-337

FAO (1989) Soil Map of the World: Legend of Soils. FAO, Rome

Fogel R, Cromack K (1977) Effect of habitat and substrate quality on Douglas fir litter decomposition in Western Oregon. Can J For Res 55, 1632-1640

Gosz JR, Likens GE, Bormann FH (1973) Nutrient release from decomposing leaf and branch litter in the Hubbard Brook Forest, New Hampshire. Ecol Monogr 43, 173-191.

Hanchi A (1994) Cycle de l'eau et des éléments biogènes dans un bassin versant forestier : cas d'une hêtraie au mont Lozère. Doctoral thesis, Université de Bourgogne, Dijon

Hayes AJ ( 1965) Studies on the decomposition of coniferous leaf litter. I. Physical and chemical changes. J Soil Sci 16, 121-140

Heal OW (1979) Decomposition and nutrient release in evenaged plantations. In: The Ecology of Evenaged Forest Plantations (ED Ford, D Malcolm, J Atterson, eds), Institute of Terrestrial Ecology, Cambridge

Hernández. IM, Santa Regina I, Gallardo JF ( 1995). Dynamics of bioelements during leaf decomposition in three forest ecosystems of semiarid climate in the Duero Basin. Arid Soil Res Rehab 9, 437-455
Lousier JD, Parkinson D (1976) Litter decomposition in a cool temperate deciduous forest. Can J Bot 54. 419-436

Martín A, Rapp M, Santa Regina I, Gallardo JF (1994) Leaf litter decomposition dynamics in some Mediterranean deciduous oaks. Eur J Soil Biol 30 , 119- 124

Meentemeyer V (1978) Macroclimate and lignin control of litter decomposition rates. Ecology 59, 465 472

Melillo JM, Aber JD, Muratore JF (1982) Nitrogen and lignin control of hardwood leaf litter decomposition dynamics. Ecology 63, 621-626

Moore AM (1986) Temperature and moisture dependence of decomposition rates of hardwood and coniferous leaf litter. Soil Biol Biochem 18, 427435.

Moreno G, Gallardo JF, Cuadrado S (1993) Consumo hídrico edático en cuatro bosques de Quercus pyrenaica de la Sierra de Gata (Provincia de Salamanca, España). In: El estudio del suelo y de su degradación en relación con la desertificación ( $\mathrm{JF}$ Gallardo, ed), Mº APA Madrid 3, 1707-1716

Rapp M (1967) Étude expérimentale de la libération d'éléments minéraux lors de la décomposition de litières d'essences méditerranéennes. CR Acad SC Paris 264, 797

Reichle DE (1977) The role of soil invertebrates in nutrient cycling. In: Soil Organisms as Components of Ecosystems (U Lohm, T Persson, eds), Ecol Bull (Stockholm) 25, 145-156

Schlesinger W (1985) Decomposition of chaparral shrub foliage. Ecology 66, 1353-1359

Seastedt TR (1984) The role of microarthropods in decomposition and mineralization processes. Ann Rev Entomol 29, 25-46.

Swift MJ, Heal OW, Anderson JM (1979) Decomposition in Terrestrial Ecosystems. University of California Press, Berkley

Will G (1967) Decomposition of Pimus radiata litter on the forest floor. Part 1. Changes in dry matter and nutrient content. $N Z J S_{c i}, 10,1030-1044$

Witkamp M (1966) Decomposition of leaf litter in relation to environment, microflora, and microbial respiration. Ecology 47, 194-201

Witkamp M, Vander Drift J (1961) Breakdown of forest litter in relation to environmental factors. Plant Soil 15, 295-311 